\title{
The heritability of beta cell function parameters in a mixed meal test design
}

\author{
A. M. C. Simonis-Bik • D. I. Boomsma • J. M. Dekker • M. Diamant • \\ E. J. C. de Geus • L. M. 't Hart • R. J. Heine • M. H. H. Kramer • J. A. Maassen • \\ A. Mari • A. Tura • G. Willemsen • E. M. W. Eekhoff
}

Received: 1 November 2010 / Accepted: 4 January 2011 /Published online: 11 February 2011

(C) The Author(s) 2011. This article is published with open access at Springerlink.com

\begin{abstract}
Aims/hypothesis We estimated the heritability of individual differences in beta cell function after a mixed meal test designed to assess a wide range of classical and modelderived beta cell function parameters.

Methods A total of 183 healthy participants (77 men), recruited from the Netherlands Twin Register, took part in a $4 \mathrm{~h}$ protocol, which included a mixed meal test. Participants were Dutch twin pairs and their siblings, aged 20 to
\end{abstract}

Electronic supplementary material The online version of this article (doi:10.1007/s00125-011-2060-5) contains supplementary material, which is available to authorised users.

A. M. C. Simonis-Bik $(\bowtie) \cdot$ M. Diamant $\cdot$ R. J. Heine $\cdot$

J. A. Maassen • E. M. W. Eekhoff

Diabetes Center, VU University Medical Center,

ZH 4A62, PO Box 7057, 1007 MB Amsterdam, the Netherlands

e-mail: amc.simonis-bik@vumc.nl

D. I. Boomsma • E. J. C. de Geus · G. Willemsen

Biological Psychology, VU University Amsterdam,

Amsterdam, the Netherlands

J. M. Dekker

Epidemiology and Biostatistics and EMGO Institute for Health and Care Research, VU University Medical Center,

Amsterdam, the Netherlands

\section{M. 't Hart}

Molecular Cell Biology and Section Molecular Epidemiology, Leiden University Medical Center,

Leiden, the Netherlands

\section{H. H. Kramer}

Internal Medicine, VU University Medical Center,

Amsterdam, the Netherlands

A. Mari $\cdot$ A. Tura

CNR Institute of Biomedical Engineering,

Padova, Italy
49 years. All members within a family were of the same sex. Insulin sensitivity, insulinogenic index, insulin response and postprandial glycaemia were assessed, as well as model-derived parameters of beta cell function, in particular beta cell glucose sensitivity and insulin secretion rates. Genetic modelling provided the heritability of all traits. Multivariate genetic analyses were performed to test for overlap in the genetic factors influencing beta cell function, waist circumference and insulin sensitivity.

Results Significant heritabilities were found for insulinogenic index (63\%), beta cell glucose sensitivity (50\%), insulin secretion during the first $2 \mathrm{~h}$ postprandial $(42-47 \%)$ and postprandial glycaemia (43-52\%). Genetic factors influencing beta cell glucose sensitivity and insulin secretion during the first 30 postprandial min showed only negligible overlap with the genetic factors that influence waist circumference and insulin sensitivity.

Conclusions/interpretation The highest heritability for postprandial beta cell function was found for the insulinogenic index, but the most specific indices of heritability of beta cell function appeared to be beta cell glucose sensitivity and the insulin secretion rate during the first $30 \mathrm{~min}$ after a mixed meal.

Keywords Gastro-entero pancreatic function - Genetics of type 2 diabetes · Human · Insulin secretion · Insulin sensitivity $\cdot$ Metabolic physiology
Abbreviations
A Additive genetic influences
C Common environmental influences
D Dominant genetic influences
E Unique environmental influences
GWA Genome-wide association
ISR Insulin secretion rate
OGIS Oral glucose insulin sensitivity 


\section{Introduction}

The pathophysiology of type 2 diabetes is characterised by insulin resistance, but the development of hyperglycaemia is mainly determined by deterioration of beta cell function [1]. Twin and family studies have confirmed a genetic contribution to type 2 diabetes [2-4]. However, the underlying processes are largely unknown. Better knowledge of genetic factors affecting different aspects of beta cell function will provide a better insight into the aetiology of this disease. One step in this search for genetic factors is to estimate the heritability (genetic influences as per cent of total variance) of well described beta cell function parameters.

Previous heritability estimates of beta cell function have been based on the calculation of indices of fasting insulin secretion and on experimental challenge tests of beta cell function, including the intravenous glucose tolerance test [3] and the hyperglycaemic clamp test [5]. These revealed significant heritability of insulin response after different intravenous secretagogues. As far as we know, only three OGTT studies have been used as oral challenge tests to estimate the heritability of beta cell function. Hanson [2] found a heritability of $25 \%$ for the corrected insulin response and others [3] estimated a heritability of $40 \%$ to $60 \%$ for OGTT-based measures of beta cell function. We chose the mixed meal test, as it combines the effect of different natural secretagogues (carbohydrates, proteins and fatty acids) including incretins and neural signals. To the best of our knowledge no previous study has specifically assessed the heritability of beta cell function parameters based on a mixed meal.

The aim of this twin family study was to explore the heritability of classical and model-derived beta cell function parameters and of postprandial glycaemia indices obtained from a mixed meal test. We used a mathematical model $[6,7]$ that clearly represents different aspects of beta cell function and is frequently applied in intervention studies (e.g. efficacy of glucose-lowering agents [8] and bariatric surgery [9]).

The main parameters are insulin secretion rate (ISR), calculated by deconvolution of C-peptide levels [10], and beta cell glucose sensitivity, which represents the doseresponse relation between insulin secretion and glucose concentration. As beta cell function is closely associated with (abdominal) overweight and insulin sensitivity, waist circumference [11] and oral glucose insulin sensitivity (OGIS) [12] were measured simultaneously. This allowed us to test to which extent genetic factors influencing the most important markers of postprandial insulin secretion (ISR, beta cell glucose sensitivity and insulinogenic index) overlap with the genetic factors that influence waist circumference and insulin sensitivity.

\section{Methods}

Participants Twin pairs and a same-sex sibling were recruited from the Netherlands Twin Register [13] as described previously [14]. Mixed meal tests were performed in 183 (77 male) healthy participants of European origin, aged 20 to 49 years. In the weeks prior to these mixed meal tests, the presence of diabetes mellitus was excluded on the basis of a $75 \mathrm{~g}$ OGTT. There were 51 monozygotic twin pairs and 21 same-sex dizygotic twin pairs from 72 families. For 15 monozygotic twin pairs and eight dizygotic twin pairs one additional same-sex sibling also took part in the study. Two monozygotic pairs and one dizygotic twin pair had two additional same-sex siblings. In five more families only one twin of the pair participated, together with a same-sex sibling. In total, 149 twins and 34 siblings participated. Twin zygosity was determined from DNA polymorphisms. In total, 68 dizygotic/sibling pairs could be formed. The mean age difference between twins and their siblings was 3.2 years, with a range of 1 to 9 years. Including additional siblings in the classical twin design significantly increases the power to detect the genetic and environmental sources of variation [15]. All participants gave written informed consent. The study was approved by the local Ethics Committee and performed in accordance with the Declaration of Helsinki.

Meal test The nutrient composition of the test meal was calculated from the Dutch Food Composition Table [16] and each portion of the ingredients was weighed before the meal was prepared. In oral beta cell function challenge tests the dose is generally the same (e.g. $75 \mathrm{~g}$ in OGTT) for all adult participants. To achieve an optimal challenge of the beta cell, we chose to give men a larger meal than women because of the mean weight difference $(10.8 \mathrm{~kg})$ between men and women participants. Because we compared only same-sex pairs, this did not confound the heritability estimates.

The meal for men consisted of $110 \mathrm{~g}$ brown bread, $20 \mathrm{~g}$ margarine, $25 \mathrm{~g}$ fat-rich cheese, $30 \mathrm{~g}$ jam, $19 \mathrm{~g}$ honey cake and $200 \mathrm{ml}$ semi-skimmed milk $(3024 \mathrm{~kJ}, 89 \mathrm{~g}$ carbohydrates [50\% energy], $30 \mathrm{~g}$ fat [37\% energy] and $24.4 \mathrm{~g}$ protein $[13 \%$ energy]). Women consumed $79 \%$ of that meal with the same proportions of nutrients and energy (2,392 kJ, $71 \mathrm{~g}$ carbohydrates, $23 \mathrm{~g}$ fat and $19.4 \mathrm{~g}$ protein).

The mixed meal test procedure was started at the research unit at 08:00 hours after a $12 \mathrm{~h}$ fast. Anthropometric measurements were performed as described previously [5]. A cannula was placed retrogradely in a heated dorsal hand vein to obtain arterialised blood. After baseline samples had been taken twice, the test meal was consumed between $t=0$ and $t=10 \mathrm{~min}$. Blood samples for glucose and hormonal levels were drawn at $t=10,20,30,40,50,60,90$, 
$120,150,180,210$ and $240 \mathrm{~min}$. During the test the participants were confined to bed and apart from the test meal, were only allowed to consume water.

Laboratory analysis Blood glucose was assessed at bedside using a glucose oxidase method (YSI 2300 Stat plus; Yellow Springs Instruments, Yellow Springs, OH, USA). This device has a within-run $\mathrm{CV}$ of $2 \%$ and a day-to-day $\mathrm{CV}$ of $6 \%$. Blood for hormonal levels was centrifuged $(1,469 \times g)$ at $4{ }^{\circ} \mathrm{C}$ and the serum stored at $-80^{\circ} \mathrm{C}$. All serum specimens were assessed for insulin and C-peptide levels at the VU University Medical Center (Department of Clinical Chemistry, Amsterdam, the Netherlands) using an immunometric assay luminescence method (ACS: Centaur; Bayer Diagnostics, Mijdrecht, the Netherlands). There was no cross-reactivity with proinsulin or split products. The interassay $\mathrm{CV}$ of insulin and C-peptide measurement was 6.5\% and $6 \%$, respectively. The intra-assay CV was $4 \%$ for both.

Classical beta cell function parameters Fasting and $2 \mathrm{~h}$ insulin levels, and the insulin incremental AUC (AUC by the trapezium rule minus the fasting level) during the entire $4 \mathrm{~h}$ test were measured. Glucose levels were analysed as follows: (1) glucose at 30 min minus fasting level: (2) glucose level at $120 \mathrm{~min}$; and (3) the glucose incremental AUC during the period from 0 to $120 \mathrm{~min}$ and during the entire $4 \mathrm{~h}$ test. As estimate of early insulin response the insulinogenic index (insulin level $t 30-t 0 /$ glucose $t 30-t 0$ ) was calculated.

Model-based beta cell function parameters ISR and modelbased beta cell function parameters were calculated using a mathematical model developed by Mari et al. [6, 7] with ISR calculated by deconvoluting C-peptide level [10].

A full description of this model can be found in the Electronic supplementary material (ESM). Briefly, in this model ISR is composed of the sum of two components, i.e. $\mathrm{P}(t) f(\mathrm{G})+\mathrm{S}_{\mathrm{d}}(t)$, which account for different aspects of beta cell function. $f(\mathrm{G})$ is the dose response that represents the static relationship between insulin and glucose concentration during the test. The average slope of this dose-response is denoted as beta cell glucose sensitivity. From the doseresponse, insulin secretion at a glucose concentration of $4.5 \mathrm{mmol} / \mathrm{l}$ (approximately fasting glucose concentration in the whole group) was also calculated. $\mathrm{P}(t)$ is the potentiation factor that modulates this dose-response relation and has been constrained to have a time average of 1 during the experimental test. It represents a relative potentiation. The second component of insulin secretion, $\mathrm{S}_{\mathrm{d}}(t)$, represents the enhancement of insulin secretion proportional to the rate of increase of plasma glucose concentration and is denoted as rate sensitivity, accounting for an initial fast rise in insulin secretion. Of the model parameters, we considered: (1) rate sensitivity; (2) beta cell glucose sensitivity; (3) the excur- sions of the potentiation factor using ratios between mean values at different time intervals (e.g. $\mathrm{P}[t 100-t 120] /$ $\mathrm{P}[t 0-t 20]$ and $\mathrm{P}[t 220-t 240] / \mathrm{P}[t 0-t 20]) ;(4)$ fasting ISR; (5) the ISR at $4.5 \mathrm{mmol} / 1$ glucose; and (6) the integral of incremental ISR during the three periods 0 to $30 \mathrm{~min}, 30$ to $120 \mathrm{~min}$ and the entire duration of the $4 \mathrm{~h}$ test.

Insulin sensitivity Insulin sensitivity (OGIS) was estimated using the meal carbohydrate dose and glucose and insulin levels during the first $2 \mathrm{~h}$ of the meal test according to methods described by Mari et al. [12].

Statistical analysis All genetic analyses were carried out in Mx [17], a structural equation modelling program specifically designed for the genetic analysis of twin and family data. All analyses were carried out on raw data using full information maximum likelihood to estimate parameters. In the multivariate analyses, multiple traits (waist circumference, OGIS, beta cell glucose sensitivity, insulinogenic index, ISR [0-30] and ISR [30-120]) were analysed simultaneously. Data were $Z$-transformed prior to multivariate analysis (mean $=0$, $\mathrm{SD}=1)$ to reduce the large differences in variance across the variables. This transformation does not affect the estimates of familial correlations or heritabilities.

In a first step, we confirmed that the variances of the variables were comparable for twins and siblings, and that

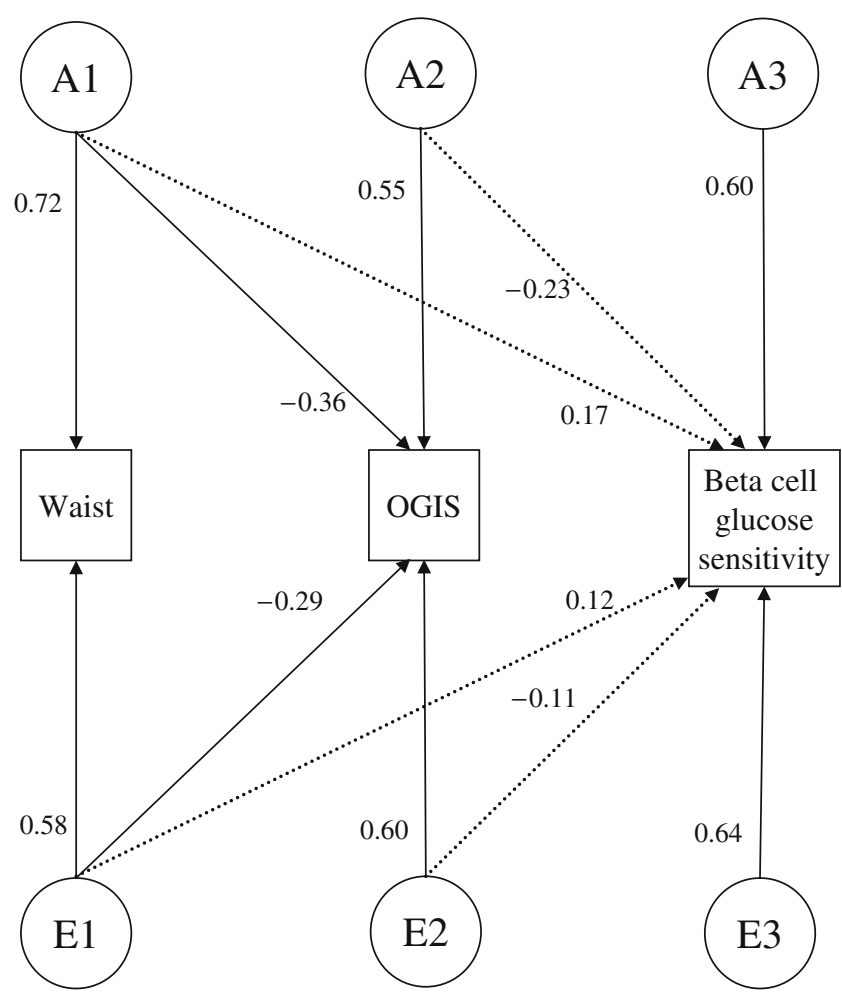

Fig. 1 Genetic model for waist, OGIS and beta cell glucose sensitivity with path loadings of observed variables on the latent $\mathrm{A}$ and $\mathrm{E}$ factors. Dotted line, non-significant 
the covariances between dizygotic twins were equal to those between a twin and a singleton sibling.

Correlations among relatives (monozygotic twin pairs, and dizygotic/sibling pairs) were estimated with age and sex as covariates. These correlations form the basis for estimation of the relative contribution of genetic and environmental factors to individual differences for a trait. Monozygotic twin pairs have all or nearly all genes in common; dizygotic/sibling pairs share on average half of their segregating genes. If monozygotic correlations are larger than dizygotic/sibling correlations, genetic influences are suggested to contribute to the trait. These influences can be additive genetic influences (A) or can act in a nonadditive manner, i.e. as dominant genetic influences (D). If the monozygotic correlations are less than twice the dizygotic/sibling correlations, common environmental influences (C) shared by family members are suggested in addition to genetic influences. The remaining sources of individual differences in the variable are unique environmental influences (E), including measurement error.

In a genetic univariate model [18], the total variance of traits was decomposed into genetic and non-genetic compo- nents for each trait. We tested for significance of components with likelihood-ratio tests. The difference in minus two times the log-likelihood (-2LL) between a full model (e.g. ACE) and a nested, more restricted model (e.g. AE) has a $\chi^{2}$ distribution with 1 degree of freedom. If the $\chi^{2}$ is significant, the parsimonious model does not fit the data. This procedure was carried out for each variable to arrive at the most parsimonious model. Under this model the heritability of each variable individually was then derived.

Multivariate analyses were performed to assess the cause of correlations between traits. We examined whether the associations among traits were explained by overlapping genetic influences. Three series of analyses were carried out: (1) of waist circumference, OGIS and beta cell glucose sensitivity; (2) of waist circumference, OGIS and the insulinogenic index; and (3) of waist circumference, OGIS, ISR (0-30) and ISR (30-120).

Trivariate genetic ACE models were fitted to the data that included three $\mathrm{A}$, three $\mathrm{C}$ and three $\mathrm{E}$ factors. The first factor influences all three variables; the next factor influences two variables and the last factor only one variable. Using likelihood-ratio tests with 3 degrees of

Table 1 Sample characteristics

\begin{tabular}{|c|c|c|c|}
\hline \multirow[t]{2}{*}{ Variable } & \multicolumn{3}{|l|}{ Participants } \\
\hline & Total & Men & Women \\
\hline$n$ & 183 & 77 & 106 \\
\hline Age (years) & $31.0 \pm 5.1$ & $30.7 \pm 4.8$ & $31.3 \pm 5.3$ \\
\hline Waist circumference $(\mathrm{cm})$ & $84.7 \pm 9.8$ & $87.4 \pm 8.5^{* *}$ & $82.8 \pm 10.3$ \\
\hline Weight $(\mathrm{kg})$ & $72.7 \pm 11.4$ & $79.0 \pm 9.3 * *$ & $68.2 \pm 10.6$ \\
\hline BMI $\left(\mathrm{kg} / \mathrm{m}^{2}\right)$ & $23.75 \pm 3.41$ & $23.96 \pm 2.94$ & $23.60 \pm 3.73$ \\
\hline OGIS ( $\left.\mathrm{ml} \mathrm{min}^{-1} \mathrm{~m}^{-2}\right)$ & $487 \pm 51$ & $471 \pm 50^{* *}$ & $498 \pm 50$ \\
\hline \multicolumn{4}{|l|}{ Model-derived beta cell function parameters } \\
\hline Beta cell glucose sensitivity (pmol $\mathrm{min}^{-1} \mathrm{~m}^{-2}[\mathrm{mmol} / \mathrm{l}]^{-1}$ ) & $131 \pm 52$ & $149 \pm 57 * *$ & $119 \pm 44$ \\
\hline Fasting ISR (pmol $\mathrm{min}^{-1} \mathrm{~m}^{-2}$ ) & $55.3 \pm 16.2$ & $54.6 \pm 17.3$ & $55.8 \pm 15.4$ \\
\hline ISR integral of increment $(0-30)\left(\mathrm{nmol} / \mathrm{m}^{2}\right)$ & $4.83 \pm 2.27$ & $5.37 \pm 2.31 *$ & $4.46 \pm 2.18$ \\
\hline ISR integral of increment $(30-120)\left(\mathrm{nmol} / \mathrm{m}^{2}\right)$ & $20.0 \pm 8.8$ & $19.1 \pm 9.1$ & $20.6 \pm 8.6$ \\
\hline ISR integral of increment $(0-240)\left(\mathrm{nmol} / \mathrm{m}^{2}\right)$ & $34.1 \pm 12.9$ & $32.2 \pm 12.6$ & $35.5 \pm 13.0$ \\
\hline 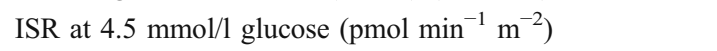 & $81.8 \pm 34.5$ & $69.3 \pm 29.1^{*}$ & $91.1 \pm 35.4$ \\
\hline Potentiation factor ratio $(100-120) /(0-20)$ & $1.26 \pm 0.34$ & $1.25 \pm 0.35$ & $1.27 \pm 0.34$ \\
\hline Potentiation factor ratio $(220-240) /(0-20)$ & $1.00 \pm 0.27$ & $1.02 \pm 0.26$ & $0.99 \pm 0.27$ \\
\hline Rate sensitivity $\left(\mathrm{pmol} \mathrm{min}^{-1} \mathrm{~m}^{-2}[\mathrm{mmol} / \mathrm{l}]^{-1}\right.$ ) & $1,135 \pm 607$ & $1,137 \pm 657$ & $1,135 \pm 573$ \\
\hline \multicolumn{4}{|l|}{ Classical beta cell function parameters } \\
\hline Insulinogenic index (pmol/mmol) & $171 \pm 88$ & $194 \pm 106^{*}$ & $156 \pm 70$ \\
\hline Fasting serum insulin $(\mathrm{pmol} / \mathrm{l})$ & $34.8 \pm 15.0$ & $33.9 \pm 16.7$ & $35.4 \pm 13.7$ \\
\hline Serum insulin at $t 120(\mathrm{pmol} / \mathrm{l})$ & $20.7 \pm 12.3$ & $19.9 \pm 13.0$ & $21.2 \pm 11.8$ \\
\hline Serum insulin IAUC $(0-240)(\mathrm{pmol} \times \mathrm{h} / \mathrm{l})$ & $613 \pm 270$ & $588 \pm 269$ & $630 \pm 271$ \\
\hline Glucose $t 30$ minus $t 0(\mathrm{mmol} / \mathrm{l})$ & $2.08 \pm 0.67$ & $2.11 \pm 0.59$ & $2.05 \pm 0.72$ \\
\hline Glucose at $t 120(\mathrm{mmol} / \mathrm{l})$ & $5.39 \pm 0.65$ & $5.29 \pm 0.55$ & $5.46 \pm 0.71$ \\
\hline Glucose IAUC $(0-120)(\mathrm{mmol} \times \mathrm{h} / \mathrm{l})$ & $2.59 \pm 1.05$ & $2.31 \pm 0.96^{*}$ & $2.80 \pm 1.07$ \\
\hline Glucose IAUC $(0-240)(\mathrm{mmol} \times \mathrm{h} / \mathrm{l})$ & $3.70 \pm 1.66$ & $2.98 \pm 1.30 * *$ & $4.23 \pm 1.71$ \\
\hline
\end{tabular}


freedom as described above, we tested whether the contributions of these $\mathrm{A}$ and $\mathrm{C}$ factors were significant. Next individual paths of each $\mathrm{A}$ and $\mathrm{E}$ factor to the three variables were tested for significance, e.g. for waist circumference, OGIS and beta cell glucose sensitivity (Fig. 1). Under this model, total heritability for each trait was estimated and decomposed into genetic influences that are specific to each trait (e.g. waist circumference, OGIS and beta cell glucose sensitivity) and genetic factors that influence two or more variables at the same time (e.g. waist circumference and OGIS). Due to the statistical procedure, slight differences in heritability estimates between the univariate and multivariate analyses are possible.

\section{Results}

Sample characteristics are shown in Table 1. Waist circumference, weight, beta cell glucose sensitivity, ISR during the first $30 \mathrm{~min}$ and the insulinogenic index were significantly higher in men. OGIS, ISR at $4.5 \mathrm{mmol} / 1$ glucose and the incremental AUC of glucose during the first $2 \mathrm{~h}$ and during the total $4 \mathrm{~h}$ mixed meal test were significantly larger in women. The influence of age was significant for waist circumference $(\beta=0.51, p=0.003)$, ISR from 30 to $120 \mathrm{~min}$ $(\beta=0.31, p=0.035)$ and OGIS $(\beta=-2.6, p=0.003)$.

Monozygotic twin pair and dizygotic/sibling pair correlations are shown in Table 2, which also presents the estimates for the percentages of variance in each trait explained by $\mathrm{A}, \mathrm{C}$ and $\mathrm{E}$ factors. Significant heritability (variance explained by additive genetic factors) was found for 13 traits and a significant contribution of shared environmental factors for four traits. No significant family resemblance was found for the potentiation factor ratios and rate sensitivity.

There were significant phenotypic correlations between beta cell glucose sensitivity and waist circumference $(r=0.21$, $p=0.01)$, beta cell glucose sensitivity and OGIS $(r=-0.33$, $p=<0.01)$, and waist circumference and OGIS $(r=-0.49$, $p<0.01)$. Figure 1 illustrates the most parsimonious $\mathrm{AE}$ model resulting from the multivariate genetic analysis. Table 3 shows the decomposition of heritabilities of these three parameters under this model. Of the $50 \%$ of variance in OGIS due to genetic factors, about one-third (15\%) was due to the same genetic factors that also influence waist circumference, whereas the remaining approximately twothirds $(35 \%)$ of the variance was due to genetic factors unique to OGIS. By contrast, the overlap of genetic factors influencing beta cell glucose sensitivity and those that influence waist circumference or OGIS was negligible.
Table 2 Twin/sib correlations and estimates for the percentage of variance explained by additive genetic influences, and common and unique environment influences

\begin{tabular}{|c|c|c|c|c|c|}
\hline \multirow[t]{2}{*}{ Variable } & \multicolumn{2}{|c|}{ Correlation per group } & \multicolumn{3}{|l|}{ Influences } \\
\hline & $\mathrm{MZ}^{\mathrm{a}}$ & DZ/sibling ${ }^{\mathrm{b}}$ & $\mathrm{A}$ & $\mathrm{C}$ & $\mathrm{E}$ \\
\hline Waist circumference & 0.60 & 0.30 & $60(40-74)$ & & $40(26-60)$ \\
\hline Weight & 0.59 & 0.25 & $57(34-73)$ & & $43(27-67)$ \\
\hline OGIS & 0.47 & 0.30 & $49(28-65)$ & & $51(35-72)$ \\
\hline \multicolumn{6}{|l|}{ Model-derived function parameters } \\
\hline Beta cell glucose sensitivity & 0.51 & 0.23 & $50(26-68)$ & & $50(32-74)$ \\
\hline Fasting ISR & 0.43 & 0.21 & $43(21-61)$ & & $57(39-79)$ \\
\hline ISR integral of increment $(0-30)$ & 0.42 & 0.31 & $45(24-62)$ & & $55(38-76)$ \\
\hline ISR integral of increment $(30-120)$ & 0.41 & 0.25 & $40(16-58)$ & & $60(42-84)$ \\
\hline ISR integral of increment (0-240) & 0.43 & 0.36 & & $40(21-56)$ & $60(44-79)$ \\
\hline ISR at $4.5 \mathrm{mmol} / 1$ glucose & 0.57 & 0.45 & & $50(34-64)$ & $50(36-66)$ \\
\hline Potentiation factor ratio $(100-120) /(0-20)$ & 0.04 & 0.09 & & $7(0-52)$ & $93(75-100)$ \\
\hline Potentiation factor ratio $(220-240) /(0-20)$ & 0.20 & 0.02 & $15(0-39)$ & & $85(61-100)$ \\
\hline Rate sensitivity & 0.18 & 0.16 & & $17(0-37)$ & $83(63-100)$ \\
\hline \multicolumn{6}{|l|}{ Classical function parameters } \\
\hline Insulinogenic index & 0.63 & 0.31 & $63(43-77)$ & & $37(23-57)$ \\
\hline Fasting serum insulin & 0.37 & 0.20 & $38(11-59)$ & & $62(41-89)$ \\
\hline Serum insulin at $t 120$ & 0.26 & 0.21 & & $24(4-43)$ & $76(57-96)$ \\
\hline Serum insulin IAUC $(0-240)$ & 0.45 & 0.41 & & $44(25-59)$ & $56(41-75)$ \\
\hline Glucose ( $t 30$ minus $t 0)$ & 0.54 & 0.17 & $52(30-68)$ & & $48(32-70)$ \\
\hline Glucose at $t 120$ & 0.51 & 0.13 & $50(30-66)$ & & $50(34-70)$ \\
\hline Glucose IAUC (0-120) & 0.58 & -0.10 & $50(31-75)$ & & $50(31-75)$ \\
\hline Glucose IAUC (0-240) & 0.48 & 0.02 & $43(19-62)$ & & $57(38-81)$ \\
\hline
\end{tabular}


Table 3 Heritability of waist, OGIS and beta cell glucose sensitivity

Values are per cent $(95 \% \mathrm{CI})$

The phenotypic correlation of insulinogenic index with waist circumference and OGIS was highly significant $(r=0.35$ and $r=-0.40$, respectively, $p<0.01$ for both). The second three-variate genetic analysis (waist circumference, OGIS and insulinogenic index) showed that this phenotypic correlation was mainly explained by genetic factors shared by waist circumference, OGIS and insulinogenic index. Table 4 shows the decomposition of heritabilities of these three parameters under the most parsimonious AE model. Of the $63 \%$ of variance in the insulinogenic index that was due to genetic factors, about one third was due to the same genetic factors that also influence waist circumference $(10 \%)$ or OGIS $(10 \%)$, whereas the remaining two-thirds $(43 \%)$ of variance were due to genetic factors unique to the insulinogenic index.

Phenotypic correlations between waist circumference, OGIS, ISR (0-30) and ISR (30-120) are given in Table 5 and were all significant. The correlations between waist circumference and insulin secretion during the first $2 \mathrm{~h}$ postprandial were smaller than those between OGIS and insulin secretion. According to the results of the fourvariate decomposition shown in Table 6 , only a very small part of the total heritability of ISR (0-30) was derived from genetic factors shared with waist circumference and OGIS, while nearly one-third of the total heritability of ISR (30-120) was derived from genetic factors influencing waist circumference and OGIS.

\section{Discussion}

This same-sex twin family study is the first to estimate the heritability of a wide range of classical and model-derived traits [6] for assessment of postprandial beta cell function.

The results show that model-derived beta cell glucose sensitivity has a high heritability $(50 \%)$ with negligible
Total heritability or part of heritability per genetic factor

\begin{tabular}{lrrr}
\hline Total & Waist & OGIS & Beta cell glucose sensitivity \\
\hline $60(40-74)$ & 60 & & \\
$50(30-66)$ & 15 & 35 & \\
$50(27-68)$ & 3 & 6 & 41 \\
\hline
\end{tabular}

overlap with genetic factors for waist circumference and insulin sensitivity. This replicates and extends findings in non-genetically related samples [19], which also showed beta cell glucose sensitivity to be largely unrelated to waist circumference and insulin sensitivity. The modest phenotypic correlation between beta cell glucose sensitivity and waist circumference probably reflects the inverse relation of beta cell glucose sensitivity and insulin sensitivity, which is, in turn, strongly related to waist circumference. Beta cell glucose sensitivity is the most important parameter of the model because it quantifies the ability of the beta cell to respond to changes in glucose concentration and is a significant independent predictor of glucose intolerance. Recent findings $[20,21]$ suggest that a number of variants in several genetic loci (near genes MTNR1B, CDKAL1, HHEX/IDE and TCF7L2) may account for the substantial heritability in beta cell glucose sensitivity.

The insulinogenic index is a classically calculated estimate of early insulin response in OGTT, described as early as 1967 [22]. It is strongly associated with the acute insulin response after intravenous glucose administration [23] and is an independent predictor of worsening of glucose tolerance [24]. In our study, the insulinogenic index (insulin level $t 30-t 0 /$ glucose $t 30-t 0$ ) was the variable with the largest heritability (63\%). This is substantially higher than the $36 \%$ heritability found when the insulinogenic index was estimated during an OGTT [25]. In spite of this lower heritability, the insulinogenic index as derived from OGTT data has led to the identification of at least 16 independent loci in genetic association studies [26-30].

The insulinogenic index and beta cell glucose sensitivity have a strong phenotypic correlation (0.68), of which $66 \%$ is explained by common genetic factors (data not shown). However, they appear to represent partly different aspects of beta cell function. Murphy [31] showed that carriers of glucokinase gene mutations have a normal insulinogenic
Table 4 Heritability of waist, OGIS and insulinogenic index

Values are per cent $(95 \% \mathrm{CI})$

\begin{tabular}{llccc}
\hline Variable & \multicolumn{4}{l}{ Total heritability or part of heritability per genetic factor } \\
\cline { 2 - 4 } & Total & Waist & OGIS & Insulinogenic index \\
\hline Waist & $60(40-74)$ & 60 & & \\
OGIS & $50(30-66)$ & 15 & 35 & 43 \\
Insulinogenic index & $63(43-77)$ & 10 & 10 & \\
\hline
\end{tabular}


Table 5 Phenotypic correlations $(95 \%$ CI) between waist, OGIS, ISR (0-30) and ISR (30-120)

\begin{tabular}{|c|c|c|c|}
\hline Variable & Waist & OGIS & $\operatorname{ISR}(0-30)^{\mathrm{a}}$ \\
\hline OGIS & $-0.50(-0.61,-0.36)$ & & \\
\hline ISR $(0-30)$ & $0.13(-0.03,0.29)$ & $-0.22(-0.37,-0.06)$ & \\
\hline ISR $(30-120)^{\mathrm{b}}$ & $0.17(0.01,0.32)$ & $-0.50(-0.61,-0.37)$ & $0.41(0.27,0.54)$ \\
\hline
\end{tabular}

a ISR (0-30) is the integral of incremental insulin secretion for 0-30 min

bISR (30-120) is the integral of incremental insulin secretion for 30-120 min

index, but, as may be expected, reduced beta cell glucose sensitivity with a large right shift. Tura [32] revealed that women with normal glucose tolerance who had previously had gestational diabetes had decreased beta cell glucose sensitivity, but a normal insulinogenic index. Mari et al. [8] demonstrated that the insulin secretagogue nateglinide improved beta cell glucose sensitivity in patients with type 2 diabetes, while the insulinogenic index did not change significantly. Despite its higher heritability, the insulinogenic index shared more genetic factors with waist circumference and insulin sensitivity than beta cell glucose sensitivity. This makes model-derived beta cell glucose sensitivity a more specific genetic marker of beta cell function.

Although the heritability of fasting insulin levels has been estimated in many studies (ranging from 8\% [33] to $54 \%$ [34]), to our knowledge the heritability of fasting ISR, which takes insulin clearance into account, has not been assessed previously. The heritability of fasting ISR and of the fasting insulin level shows the same order of magnitude ( $43 \%$ and $38 \%$, respectively), with high correlation between the two insulin measurements $(0.80)$. However, fasting ISR is a better measure of the activity of the beta cell than insulin level, as it also takes insulin clearance into account. Waist circumference and OGIS were less correlated with ISR (0-30) than with ISR (30-120). Moreover, overlap of the genetic influences on waist circumference, OGIS and ISR during the first 30 min postprandial was smaller than that on waist circumference, OGIS and the later insulin secretion period (30-120). This is again compatible with the relatively high number of genetic loci found in genomewide association (GWA) studies to be associated with early insulin secretion [28], while only two genetic loci have been found to be significantly associated with reduced insulin secretion during the $2 \mathrm{~h}$ OGTT $[29,35]$.

All postprandial glycaemia parameters were significantly influenced by genetic factors, with heritability estimates ranging between $43 \%(4 \mathrm{~h})$ and $52 \%$ (first $30 \mathrm{~min}$ ). Heritability of the other mixed meal test parameters, i.e. ISR (0-240), ISR at $4.5 \mathrm{mmol}$ glucose, potentiation factor ratios $(100-120) /(0-20)$ and $(220-240) /(0-20)$, rate sensitivity, serum insulin at $t 120$ and serum insulin incremental AUC (0-240), was not significant, although in many instances the monozygotic twin pair correlation was larger than the dizygotic/sibling pair correlation. This may reflect the major limitation of the approach used in this study, namely the limited sample size of only 183 participants. The power of our study to detect a univariate heritability of $40 \%$ was only $50 \%(\alpha=0.05)$ [15]. Because meal size [36], meal composition [37] and rate of gastric emptying [38] influence postprandial insulin secretion and glycaemia, a strict protocol was required with adequately trained assistance and researchers.

It is known that intrauterine circumstances (according to the thrifty genotype and thrifty phenotype hypothesis) may influence beta cell function and insulin sensitivity in later life by non-genetic [39] and genetic [40] mechanisms. In our cohort the mean birthweight of monozygotic and

Table 6 Heritability of waist, OGIS, ISR (0-30) and ISR (30-120)

\begin{tabular}{lcccc}
\hline Variable & \multicolumn{2}{l}{ Total heritability or part of heritability per genetic factor } & \\
\cline { 2 - 5 } & Total heritability & Waist & OGIS & ${\text { ISR }(0-30)^{\mathrm{a}}}^{\text {ISR }(30-120)^{\mathrm{b}}}$ \\
\hline Waist & $62(42-75)$ & 62 & & \\
OGIS & $50(30-66)$ & 15 & 35 & 42 \\
ISR (0-30) & $47(26-63)$ & 2 & 3 & 8 \\
ISR (30-120) & $42(19-61)$ & 6 & 7 & 21 \\
\hline
\end{tabular}

Values are per cent $(95 \% \mathrm{CI})$

${ }^{\text {a ISR }}(0-30)$ is the integral of incremental insulin secretion for 0-30 min

${ }^{\mathrm{b}}$ ISR (30-120) is the integral of incremental insulin secretion for 30-120 min 
dizygotic twins was comparable $(2,520$ and $2,523 \mathrm{~g}$, respectively), but siblings had a significantly higher birthweight $(3,623 \mathrm{~g})$. Nevertheless, we did not find significant differences in the means of insulin sensitivity and beta cell function parameters between twins and siblings, possibly because of the young age of our participants or the small number.

Until now GWA studies have only used results of OGTT to test beta cell function and glucose tolerance after a glucose challenge [41, 42]. The mixed meal has several advantages over the OGTT, as it stimulates insulin secretion to a greater extent [43] and through a more physiological pathway; it is also a better reflection of daily life. This makes the mixed meal test a powerful method to study the effects of candidate genetic variants deriving from GWA studies in more detail.

In summary, we found that the highest heritability for postprandial beta cell function was for the classical insulinogenic index, but the most specific beta cell function parameters appeared to be model-derived beta cell glucose sensitivity and the integral of incremental ISR during the first 30 min postprandial. We conclude that the mixed meal test detects multiple heritable aspects of beta cell function that can help us examine the biology underlying the wealth of genetic variants produced by GWA studies.

Acknowledgements This study was supported financially by the Dutch Diabetes Research Foundation (DFN2002-00-001) and the Dutch Organization for Scientific Research (NWO-MAGW 480-04004; NWO/SPI 56-464-14192).

Duality of interest The authors declare that there is no duality of interest associated with this manuscript.

Open Access This article is distributed under the terms of the Creative Commons Attribution Noncommercial License which permits any noncommercial use, distribution, and reproduction in any medium, provided the original author(s) and source are credited.

\section{References}

1. Nijpels G, Popp-Snijders C, Kostense PJ, Bouter LM, Heine RJ (1996) Fasting proinsulin and 2-h post-load glucose levels predict the conversion to NIDDM in subjects with impaired glucose tolerance: the Hoorn Study. Diabetologia 39:113-118

2. Hanson RL, Imperatore G, Narayan KM et al (2001) Family and genetic studies of indices of insulin sensitivity and insulin secretion in Pima Indians. Diabetes Metab Res Rev 17:296-303

3. Lehtovirta M, Kaprio J, Groop L, Trombetta M, Bonadonna RC (2005) Heritability of model-derived parameters of beta cell secretion during intravenous and oral glucose tolerance tests: a study of twins. Diabetologia 48:1604-1613

4. Medici F, Hawa M, Ianari A, Pyke DA, Leslie RD (1999) Concordance rate for type II diabetes mellitus in monozygotic twins: actuarial analysis. Diabetologia 42:146-150
5. Simonis-Bik AM, Eekhoff EM, de Moor MH et al (2009) Genetic influences on the insulin response of the beta cell to different secretagogues. Diabetologia 52:2570-2577

6. Mari A, Schmitz O, Gastaldelli A, Oestergaard T, Nyholm B, Ferrannini E (2002) Meal and oral glucose tests for assessment of beta-cell function: modeling analysis in normal subjects. Am J Physiol Endocrinol Metab 283:E1159-E1166

7. Mari A, Ferrannini E (2008) Beta-cell function assessment from modelling of oral tests: an effective approach. Diabetes Obes Metab 10(Suppl 4):77-87

8. Mari A, Gastaldelli A, Foley JE, Pratley RE, Ferrannini E (2005) Beta-cell function in mild type 2 diabetic patients: effects of 6-month glucose lowering with nateglinide. Diabetes Care 28:1132-1138

9. Camastra S, Manco M, Mari A et al (2007) Beta-cell function in severely obese type 2 diabetic patients: long-term effects of bariatric surgery. Diabetes Care 30:1002-1004

10. Van Cauter E, Mestrez F, Sturis J, Polonsky KS (1992) Estimation of insulin secretion rates from C-peptide levels. Comparison of individual and standard kinetic parameters for C-peptide clearance. Diabetes 41:368-377

11. Huxley R, James WPT, Barzi F et al (2008) Ethnic comparisons of the cross-sectional relationships between measures of body size with diabetes and hypertension. Obes Rev 9(Suppl 1):53-61

12. Mari A, Pacini G, Brazzale AR, Ahren B (2005) Comparative evaluation of simple insulin sensitivity methods based on the oral glucose tolerance test. Diabetologia 48:748-751

13. Boomsma DI, de Geus EJC, Vink JM et al (2006) Netherlands Twin Register: from twins to twin families. Twin Res Hum Genet 9:849-857

14. Simonis-Bik AM, Eekhoff EM, Diamant M et al (2008) The heritability of HbA1c and fasting blood glucose in different measurement settings. Twin Res Hum Genet 11:597-602

15. Posthuma D, Boomsma DI (2000) A note on the statistical power in extended twin designs. Behav Genet 30:147-158

16. Dutch Nutrition Center (2006) NEVO table Netherlands. NEVO Foundation, The Hague

17. Neale MC, Boker SM, Xie G, Maes HH (2006) Mx: statistical modeling, 7th edn. Department of Psychiatry at Virginia Commonwealth University, Richmond

18. Neale MC, Cardon LR (1992) Methodology for genetic studies of twins and families. Kluwer, Dordrecht

19. Walker M, Mari A, Jayapaul MK, Bennett SMA, Ferrannini E (2005) Impaired beta cell glucose sensitivity and whole-body insulin sensitivity as predictors of hyperglycaemia in non-diabetic subjects. Diabetologia 48:2470-2476

20. Langenberg C, Pascoe L, Mari A et al (2009) Common genetic variation in the melatonin receptor $1 \mathrm{~B}$ gene (MTNR1B) is associated with decreased early-phase insulin response. Diabetologia 52:1537-1542

21. Pascoe L, Frayling TM, Weedon MN et al (2008) Beta cell glucose sensitivity is decreased by $39 \%$ in non-diabetic individuals carrying multiple diabetes-risk alleles compared with those with no risk alleles. Diabetologia 51:1989-1992

22. Seltzer HS, Allen EW, Herron ALJ, Brennan MT (1967) Insulin secretion in response to glycemic stimulus: relation of delayed initial release to carbohydrate intolerance in mild diabetes mellitus. J Clin Invest 46:323-335

23. Tura A, Kautzky-Willer A, Pacini G (2006) Insulinogenic indices from insulin and C-peptide: comparison of beta-cell function from OGTT and IVGTT. Diabetes Res Clin Pract 72:298-301

24. Weyer C, Tataranni PA, Bogardus C, Pratley RE (2001) Insulin resistance and insulin secretory dysfunction are independent predictors of worsening of glucose tolerance during each stage of type 2 diabetes development. Diabetes Care 24:89-94 
25. Hsueh WC, Silver KD, Pollin TI et al (2007) A genome-wide linkage scan of insulin level derived traits: the Amish Family Diabetes Study. Diabetes 56:2643-2648

26. Grarup N, Andersen G, Krarup NT et al (2008) Association testing of novel type 2 diabetes risk alleles in the JAZF1, CDC123/CAMK1D, TSPAN8, THADA, ADAMTS9, and NOTCH2 loci with insulin release, insulin sensitivity, and obesity in a population-based sample of 4,516 glucose-tolerant middleaged Danes. Diabetes 57:2534-2540

27. Holmkvist J, Banasik K, Andersen G et al (2009) The type 2 diabetes associated minor allele of rs $2237895 \mathrm{KCNQ} 1$ associates with reduced insulin release following an oral glucose load. PLoS ONE 4:e5872

28. Ingelsson E, Langenberg C, Hivert MF et al (2010) Detailed physiologic characterization reveals diverse mechanisms for novel genetic loci regulating glucose and insulin metabolism in humans. Diabetes 59:1266-1275

29. Saxena R, Hivert MF, Langenberg $C$ et al (2010) Genetic variation in GIPR influences the glucose and insulin responses to an oral glucose challenge. Nat Genet 42:142-148

30. Stancakova A, Kuulasmaa T, Paananen J et al (2009) Association of 18 confirmed susceptibility loci for type 2 diabetes with indices of insulin release, proinsulin conversion, and insulin sensitivity in 5, 327 non-diabetic Finnish men. Diabetes 58:2129-2136

31. Murphy R, Tura A, Clark PM, Holst JJ, Mari A, Hattersley AT (2009) Glucokinase, the pancreatic glucose sensor, is not the gut glucose sensor. Diabetologia 52:154-159

32. Tura A, Mari A, Winzer C, Kautzky-Willer A, Pacini G (2006) Impaired beta-cell function in lean normotolerant former gestational diabetic women. Eur J Clin Invest 36:22-28

33. Henkin L, Bergman RN, Bowden DW et al (2003) Genetic epidemiology of insulin resistance and visceral adiposity. The IRAS Family Study design and methods. Ann Epidemiol 13:211-217

34. Mayer EJ, Newman B, Austin MA et al (1996) Genetic and environmental influences on insulin levels and the insulin resistance syndrome: an analysis of women twins. Am J Epidemiol 143:323-332

35. Sparso T, Andersen G, Nielsen T et al (2008) The GCKR rs780094 polymorphism is associated with elevated fasting serum triacylglycerol, reduced fasting and OGTT-related insulinaemia, and reduced risk of type 2 diabetes. Diabetologia 51:70-75

36. Vilsboll T, Krarup T, Sonne J et al (2003) Incretin secretion in relation to meal size and body weight in healthy subjects and people with type 1 and type 2 diabetes mellitus. J Clin Endocrinol Metab 88:2706-2713

37. Rijkelijkhuizen JM, McQuarrie K, Girman CJ et al (2010) Effects of meal size and composition on incretin, alpha-cell, and beta-cell responses. Metabolism 59:502-511

38. Gentilcore D, Chaikomin R, Jones KL et al (2006) Effects of fat on gastric emptying of and the glycemic, insulin, and incretin responses to a carbohydrate meal in type 2 diabetes. J Clin Endocrinol Metab 91:2062-2067

39. Grunnet L, Vielwerth S, Vaag A, Poulsen P (2007) Birth weight is nongenetically associated with glucose intolerance in elderly twins, independent of adult obesity. J Intern Med 262: 96-103

40. Freathy RM, Mook-Kanamori DO, Sovio U et al (2010) Variants in ADCY5 and near CCNL1 are associated with fetal growth and birth weight. Nat Genet 42:430-435

41. Dupuis J, Langenberg C, Prokopenko I et al (2010) New genetic loci implicated in fasting glucose homeostasis and their impact on type 2 diabetes risk. Nat Genet 42:105-116

42. Staiger H, Machicao F, Fritsche A, Haring HU (2009) Pathomechanisms of type 2 diabetes genes. Endocr Rev 30: $557-585$

43. Rijkelijkhuizen JM, Girman CJ, Mari A et al (2009) Classical and model-based estimates of beta-cell function during a mixed meal vs an OGTT in a population-based cohort. Diabetes Res Clin Pract $83: 280-288$ 